\author{
Adam Adamczyk \\ Uniwersytet Szczeciński \\ e-mail: adam.adamczyk@wneiz.pl
}

\title{
Leszek Morawski
}

Instytut Nauk Ekonomicznych PAN

e-mail: 1morawski15@gmail.com

\section{ANALIZA ZMIAN BODŹCÓW FINANSOWYCH DO PODEJMOWANIA SAMOZATRUDNIENIA Z WYKORZYSTANIEM MODELU MIKROSYMULACYJNEGO*}

\section{ANALYSIS OF FINANCIAL STIMULUS FOR SELF-EMPLOYMENT WITH THE USE OF MICROSIMULATION MODEL}

DOI: $10.15611 / \mathrm{pn} .2018 .533 .01$

JEL Classification: H21, H31

\begin{abstract}
Streszczenie: Problem samozatrudnienia jest zjawiskiem nieneutralnym dla gospodarki. Jednocześnie państwa świadomie lub nie tworzą bodźce zachęcające do podejmowania samozatrudnienia. Celem pracy było określenie, jak zmiany, które zaszły w latach 2015-2017 w polskim systemie obciążeń fiskalnych oraz transferów socjalnych, wpłynęły na opłacalność samozatrudnienia. Dotychczasowe analizy uwzględniały jedynie wpływ obciążeń podatkowych na bodźce do podejmowania pracy na własny rachunek. W artykule zastosowano kompleksowe podejście uwzględniające zarówno opodatkowanie dochodu, składki na ubezpieczenia społeczne, jak i transfery socjalne, co było możliwe dzięki wykorzystaniu modelu mikrosymulacyjnego EUROMOD. Przeprowadzone analizy pozwoliły na sformułowanie wniosku, że analizowane zmiany wpłynęły w niejednakowy sposób na gospodarstwa domo-
\end{abstract}

* Autorzy pragną podziękować uczestnikom seminariów w Centrum Analiz Ekonomicznych CenEA (Szczecin), a w szczególności Michałowi Myckowi - za cenne uwagi i komentarze do wcześniejszych wersji pracy. Prezentowane wyniki zostały uzyskane z wykorzystaniem modelu EUROMOD w wersji H1.0 +. EUROMOD jest utrzymywany, rozwijany i zarządzany przez Instytut Badań Społeczno-Ekonomicznych (ISER) na Uniwersytecie w Essex, we współpracy z krajowymi zespołami z państw członkowskich UE. Jesteśmy wdzięczni wielu osobom, które przyczyniły się do rozwoju EUROMOD. Proces rozszerzania i aktualizowania EUROMOD jest wspierany finansowo w ramach programu Unii Europejskiej na rzecz zatrudnienia i innowacji społecznych „Easi” (2014-2020). Za wyniki i ich intepretację odpowiedzialni są autorzy artykułu. 
we o różnej strukturze. Nie zmniejszyły one znacznie opłacalności podejmowania pracy na własny rachunek przez jednoosobowe gospodarstwa domowe, dość istotnie ograniczyły one jednak opłacalność samozatrudnienia w wieloosobowych gospodarstwach domowych.

Słowa kluczowe: samozatrudnienie, bodźce, podatek dochodowy, składki na ubezpieczenia społeczne, świadczenia społeczne.

Summary: The problem of self-employment is a non-neutral phenomenon for the economy. At the same time, states consciously or not create incentives to take up self-employment. The aim of the work was to determine how the changes that had taken place in 2015-2017 in the Polish system of fiscal burdens and social transfers affected the profitability of self-employment. Previous analyzes only took into account the impact of tax burdens on incentives to take up self-employment. The work applied a comprehensive approach, taking into account both fiscal contributions and social transfers which was possible thanks to the EUROMOD microsimulation model. The survey leads to a conclusion that the analyzed changes affected in an uneven way households with different structure. While they did not significantly reduce the profitability of self-employment by single-person households, they significantly limited the profitability of self-employment in multi-person households.

Keywords: self-employment, incentives, personal income tax, social security contributions, social benefits.

\section{Wstęp}

Problem publicznego wspierania samozatrudnienia ciągle pozostaje przedmiotem dyskusji ekonomistów. Z jednej strony podkreśla się pozytywny wpływ samozatrudnienia dla tworzenia nowych miejsc pracy, $\mathrm{z}$ drugiej strony dostrzega się jego negatywne skutki przejawiające się w tworzeniu nowej niestabilnej ekonomicznie klasy społecznej - prekariatu.

Niezależnie od oceny tego zjawiska rządzący powinni być świadomi, jak szeroko rozumiana polityka państwa wpływa na opłacalność podejmowania samozatrudnienia. Należy przy tym zauważyć, że państwo może tworzyć bodźce do samozatrudnienia w sposób bezpośredni - np. poprzez udzielanie pomocy finansowej $\mathrm{w}$ formie dotacji czy grantów osobom rozpoczynającym działalność gospodarczą oraz pośrednio z wykorzystaniem instrumentów polityki podatkowej czy transferów socjalnych. Pośrednie oddziaływanie państwa na bodźce do samozatrudnienia jest często jedynie skutkiem ubocznym wprowadzanych $\mathrm{w}$ innych celach regulacji. W związku z tym wpływ określonych przepisów na opłacalność samozatrudnienia nie zawsze jest $\mathrm{w}$ pełni uświadamiany przez rządzących. Prowadzone dotychczas analizy ograniczają się zazwyczaj jedynie do określenia wpływu pojedynczych składowych polityki państwa na skłonność do podejmowania pracy na własny rachunek. Należy jednak pamiętać, że opodatkowanie, składki na ubezpieczenia społeczne, jak i transfery socjalne wzajemnie się warunkują. Występowanie sprzężeń między obciążeniami fiskalnymi a transferami socjalnymi implikuje konieczność podjęcia całościowej analizy. 
Celem niniejszego artykułu jest kompleksowa ocena wpływu wprowadzonych w Polsce w latach 2015-2017 zmian opodatkowania dochodów osób fizycznych, wysokości składek na ubezpieczenia społeczne oraz w systemie transferów socjalnych na opłacalność podejmowania samozatrudnienia.

Kompleksowa ocena wpływu obciążeń fiskalnych oraz transferów socjalnych możliwa jest dzięki wykorzystaniu modelu mikrosymulacyjnego EUROMOD.

\section{Analiza przesłanek wspierania samozatrudnienia}

Dokonanie oceny zmian w polityce podatkowo-świadczeniowej państwa z punktu widzenia jej oddziaływania na skłonność do samozatrudnienia wymaga w pierwszej kolejności odpowiedzi na pytanie, czy państwo powinno wspierać samozatrudnienie. Wspieranie samozatrudnienia mogłoby być uzasadnione dzięki wykazaniu, że dzięki niemu powstają pozytywne efekty zewnętrzne związane z faktem, że małe przedsiębiorstwa mogą być szczególnie innowacyjne, tworząc innowacje produktowe i procesowe, które łatwo mogą być zaadaptowane przez większe firmy.

Drugi argument przemawiający za stosowaniem przez państwo polityki nakierowanej na wspieranie samozatrudnienia związany jest $z$ faktem, iż sprzyja ono walce $\mathrm{z}$ bezrobociem. Samozatrudnienie odegrało istotną rolę w przywracaniu równowagi europejskiego rynku pracy po okresie kryzysu. W wielu państwach jest ono postrzegane jako skuteczny i tani sposób na walkę z bezrobociem. Jednak rola polityki samozatrudnienia jako rozwiązania problemu bezrobocia bywa kwestionowana. Shane [2009] stwierdził, że zachęty do zakładania małych firm powinny zostać wyeliminowane, gdyż przyciągają najgorszych przedsiębiorców. Opinii tej przeczą jednak analizy, które przeprowadzili Dvouletý oraz Lukeš [2016]. Badacze ci zestawili wyniki 18 badań empirycznych dotyczących wpływu polityki wspierania samozatrudnienia na poziom bezrobocia. Większość badań potwierdza pozytywne skutki wspierania samozatrudnienia dla aktywności zawodowej byłych bezrobotnych oraz ich dochodów osobistych. Dowiedziono również, że promowanie samozatrudnienia prowadzi do wydłużenia okresu przeżywalności małych firm [Dvouletý, Lukeš 2016].

Innym argumentem przemawiającym za potrzebą wspierania samozatrudnienia jest to, że w gospodarce powstaje zbyt mało firm w stosunku do optymalnego poziomu, co jest konsekwencją istniejących barier wejścia.

Zauważa się jednak, że wspieranie samozatrudnienia nie przynosi wyłącznie pozytywnych efektów ekonomicznych, ale wiąże się także ze zjawiskami ujemnie wpływającymi na gospodarkę. Crawford i Freedman [2010] są zwolenniczkami ujednolicenia stóp opodatkowania dochodów z pracy pracowników najemnych i pracujących na własnych rachunek. Stoją one na stanowisku, że zróżnicowane stopy zachęcają do nieefektywnej ekonomicznie optymalizacji podatkowej poprzez substytucję między odpowiednimi bazami podatkowymi. Przenoszenie działalności pomiędzy dwoma systemami podatkowymi o różnych krańcowych i przeciętnych stopach podatkowych powoduje zróżnicowanie opodatkowania pracy niemające 
swojego odzwierciedlenia w produktywności pracy. Powstająca w ten sposób sytuacja nierówności poziomej w opodatkowaniu pracy ma negatywne konsekwencje dla zróżnicowania dochodów do dyspozycji. Badania Gordona i Slemroda [2000] dotyczące efektów reformy podatkowej wprowadzonej w USA w 1986 r. potwierdzają wpływ zmian podatkowych na wybór formy prowadzenia działalności. Wpływ różnic $\mathrm{w}$ opodatkowaniu dochodów z pracy na wybór pomiędzy pracą na własny rachunek a zatrudnieniem najemnym został także potwierdzony w [Bruce 2000]. Harju i Matikka [2013] potwierdzili znaczenie przesuwania dochodu między bazami podatkowymi w Finlandii. Można zatem przyjąć, że preferencje podatkowe dla pewnych grup podatników (samozatrudnieni) spowodują nie tylko negatywne konsekwencje dla zróżnicowania dochodów, ale także negatywne efekty fiskalne wynikające z przesunięcia dochodów do bazy podatkowej o niższym opodatkowaniu. Przy negatywnych efektach dystrybucyjnych i fiskalnych preferencyjne opodatkowanie dochodów z działalności na własny rachunek może być uzasadnione innowacyjnym charakterem działalności. Angażowanie się w taką działalność wiąże się często z koniecznością ponoszenia wyższego ryzyka niepowodzenia, co stanowi ekonomiczny argument dla stosowania preferencji podatkowych. Jednak w odniesieniu do samozatrudnienia istnieją uzasadnione obawy utożsamiania znaczącej częśsi takich aktywności z innowacjami. Decker i in. [2014], analizując zmiany w gospodarce amerykańskiej w latach 1980-2010, dochodzą bowiem do wniosku, że o ile krótkookresowy pozytywny wpływ startupów i małych firm na zatrudnienie nie ulega wątpliwości, o tyle długookresowy wpływ na zatrudnienie i produktywność nie jest już tak oczywisty. Jest to spowodowane tym, że większość nowo powstających firm szybko kończy działalność, a tylko nieliczne spośród tych, które przeżywają, nastawione są na wzrost zatrudnienia i rozwój produkcji. Podobne wnioski znajdują się również w [Haltiwanger, Jarmin, Miranda 2013]. Block i Sandner [2009] na przykładzie Niemiec analizują konsekwencje różnic w motywacji prowadzenia własnego przedsiębiorstwa. Autorzy porównali przeżywalność dwóch typów przedsiębiorców: opportunity entrepreneurs (chęć wykorzystania zauważonej możliwości na rynku) i necessity entrepreneurs (brak innej satysfakcjonującej możliwości uzyskania dochodu), wskazując na istnienie ekonomicznych argumentów za wspieraniem przez państwo drugiego z rodzajów samozatrudnienia przy równoczesnym akcentowaniu konieczności szczegółowego adresowania takiej pomocy ze względu na wysokie ryzyko upadłości firmy. Mając zatem na względzie wysoki odsetek samozatrudnionych szybko kończących działalność oraz niską dynamikę wzrostu w długim okresie, można stwierdzić, że specjalne preferencje podatkowe dla samozatrudnionych nie znajdują swojego uzasadnienia w innowacyjności ich aktywności.

Niepożądaną konsekwencją preferencji podatkowych dla samozatrudnionych jest także nakłanianie przez pracodawców pracowników najemnych do wykonywania pracy na zasadach samozatrudnienia (bogus self-employment). Ta „optymalizacja podatkowa", przynosząca potencjalne krótkookresowe korzyści podatkowe dla obydwu stron, ma negatywne konsekwencje fiskalne oraz długookresowe dla dochodów emerytalnych pracowników. 
Z przytoczonych rozważań wynika, że poglądy na temat wspierania samozatrudnienia są znacząco zróżnicowane. Niezależnie od tego, czy racja leży po stronie zwolenników czy przeciwników tworzenia bodźców dla samozatrudnienia, problem ten nie jest neutralny dla gospodarki. Oznacza to, że istnieje potrzeba analizy siły i kierunku bodźców zachęcających lub zniechęcających do podejmowania pracy na własny rachunek.

\section{Wpływ bodźców finansowych na wybór formy zatrudnienia}

Badanie zmian finansowych bodźców do podejmowania samozatrudnienia ma sens jedynie przy założeniu, że obciążenia fiskalne oraz transfery mogą faktycznie wpłynąć na podejmowane przez pracowników decyzje. W literaturze przedmiotu najczęściej wskazuje się, że na wybór samozatrudnienia wpływ może mieć opodatkowanie. J. Mirrlees i inni twierdzą, że w długim terminie opodatkowanie wynagrodzeń może wpływać na decyzje dotyczące wyboru kariery, wykształcenia, doszkalania oraz wyboru między zatrudnieniem a samozatrudnieniem. Z kolei M. Feldstein [1999] twierdzi, że projektując skale podatkowe, należy wziąć pod uwagę reakcje podatników dotyczące skłonności do świadczenia pracy, a także wyboru zawodu czy podjęcia samozatrudnienia. Teza o istnieniu związku między opodatkowaniem a samozatrudnieniem znajduje także potwierdzenie w badaniach, które przeprowadzili Long [1982], Moore [1983], Blau [1987], Parker [1996] i Scheutze [1998].

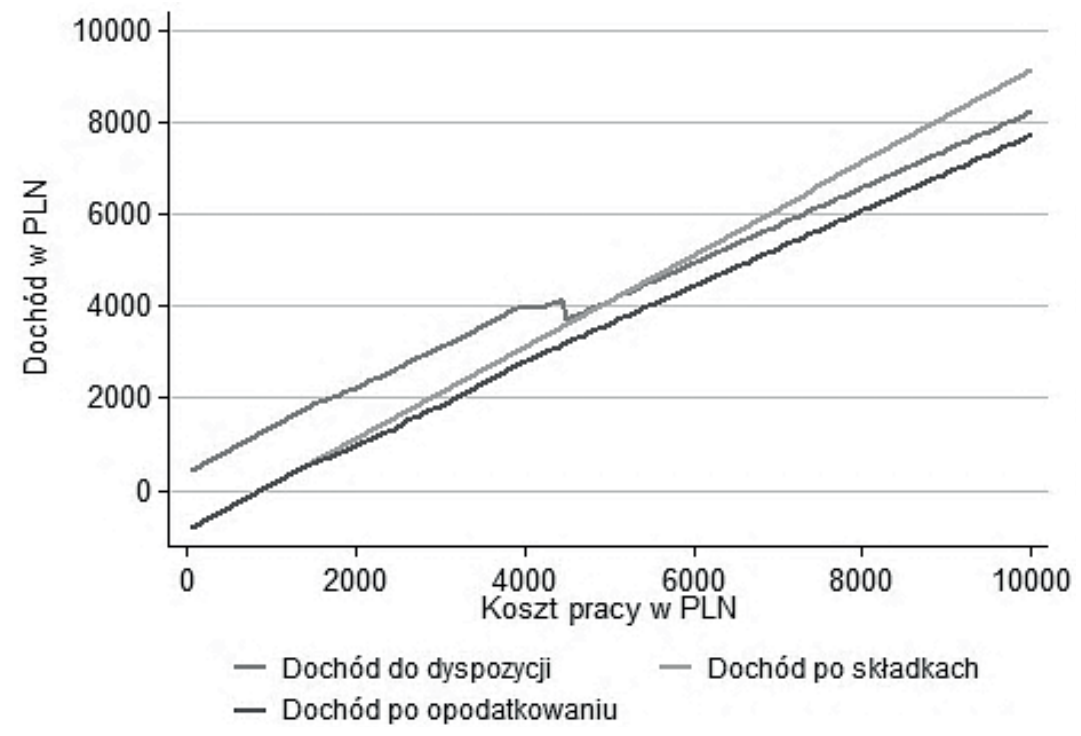

Rys. 1. Dochód brutto a dochód do dyspozycji gospodarstwa domowego $2+2$

Źródło: opracowanie własne. 
Jak wynika z przytoczonej literatury, analizując wpływ państwa na decyzje o samozatrudnieniu, zwykle uwzględnia się jedynie skutki opodatkowania. Jednak w rzeczywistości na zachowania gospodarstw domowych mogą oddziaływać wszystkie elementy kształtujące ostateczny ich dochód - to znaczy dochód do dyspozycji, a zatem zarówno podatki, składki na ubezpieczenia społeczne, jak i transfery socjalne. Jak istotne różnice zachodzą między dochodem brutto (po składkach) dochodem po opodatkowaniu oraz dochodem do dyspozycji gospodarstwa domowego składającego się z jednej osoby pracującej oraz współmałżonka i dwójki dzieci, zaprezentowano na wykresie na rys. 1.

Z wykresu wynika, że poszczególne kategorie dochodu różnią się nie tylko poziomem, ale także rozkładem w funkcji kosztu pracy. Należy podkreślić, że zarówno składki na ubezpieczenia społeczne, jak i transfery socjalne są ze sobą ściśle powiązane. Poziom składek na ubezpieczenia emerytalne wpływa na wysokość podatku, a poziom dochodu, który jest kształtowany przez składki oraz podatki, decyduje o wysokości transferów socjalnych.

\section{Wykorzystanie modeli mikrosymulacyjnych w badaniu konsekwencji zmian w polityce państwa}

Interesującą możliwością badania wpływu polityki gospodarczej na decyzje dotyczące aktywności na rynku pracy jest zastosowanie podejścia mikrosymulacyjnego wykorzystującego model podatkowo-zasiłkowy. W ekonomii to podejście ma swój początek w pracy [Orcutt 1957], która zawierała sugestię dotyczącą wykorzystania dużych zbiorów danych $\mathrm{w}$ analizie zjawisk będących konsekwencją działań zróżnicowanych podmiotów. Analizy związane z wpływem polityki gospodarczej na indywidualne decyzje na rynku pracy oraz ich konsekwencje dla zróżnicowania dochodów są naturalnymi obszarami badawczymi, w których podejście mikrosymulacyjne znalazło szerokie zastosowanie (patrz: [Figari, Paulus, Sutherland 2014]). Postęp technologiczny związany z upowszechnieniem komputerów oraz szerszy dostęp do dużych, jednostkowych zbiorów danych przyczynił się do tego, że już na przełomie lat 70. i 80. XX wieku zaczęto budować pierwsze podatkowo-zasiłkowe modele mikrosymulacyjne służące analizie wpływu regulacji podatkowo-zasiłkowych. Ideą takiego modelu jest połączenie informacji znajdujących się $\mathrm{w}$ reprezentatywnych zbiorach danych opisujących cechy pojedynczych obserwacji ze szczegółowymi regulacjami podatkowymi i świadczeniowymi determinującymi różnicę między dochodem brutto a dochodem netto. W przypadku modeli podatkowo-zasiłkowych jednostką najczęściej jest osoba, a dochodem jest dochód z pracy. Model taki pozwala na prześledzenie efektów wynikających ze zmian w przepisach podatkowych dla wartości dochodów osoby oraz jej rodziny i gospodarstwa domowego. Modele mikrosymulacyjne mogą wykorzystywać także dane sztuczne - umożliwiające porównania charakterystyk systemów podatkowo-świadczeniowych w czasie i przestrzeni. 
Przykładem takiego modelu jest wykorzystany w tej pracy model EUROMOD. Model ten wykorzystuje dane indywidualne $\mathrm{z}$ badania EU-SILC (Europejskie badanie warunków życia i dochodów). Wsadowa baza danych zawiera m.in. informacje o indywidualnych źródłach dochodów z pracy najemnej, pracy na własny rachunek oraz świadczeń i transferów społecznych. Oprócz tego dostępne są informacje o cechach socjodemograficznych poszczególnych członków rodziny i gospodarstwa domowego, dzięki czemu możliwe jest symulowanie wartości dochodów netto z pracy dla poszczególnych osób oraz dochodu do dyspozycji rodziny i gospodarstwa domowego na podstawie informacji o dochodach brutto. Szczegółowy opis bazy danych oraz działania modelu można znaleźć w [Sutherland, Figari 2013].

\section{Badanie wpływu zmian w systemie obciążeń fiskalnych oraz systemie transferów socjalnych na opłacalność wyboru samozatrudnienia}

Dotychczasowy wywód pozwolił dowieść, że samozatrudnienie nie jest zjawiskiem neutralnym dla gospodarki oraz że bodźce płynące z systemu obciążeń fiskalnych oraz transferów socjalnych nie pozostają obojętne dla samozatrudnienia. Płynie stąd wniosek, że dokonując zmian w opodatkowaniu, składkach na ubezpieczenia społeczne czy transferach, powinno uwzględnić się ich wpływ na bodźce do samozatrudnienia. Aby odpowiedzieć na pytanie, czy i kiedy system obciążeń fiskalnych oraz transferów tworzy impulsy zachęcające do samozatrudnienia, wykorzystana zostanie analiza dochodu do dyspozycji, jaki ostatecznie zostanie osiągnięty przez zatrudnionych/samozatrudnionych przy danym poziomie kosztu pracy.

W opracowaniu przyjęto, że podstawą prowadzonych symulacji będzie dochód brutto-brutto określany także jako koszt pracy. Wynikało to z założenia, że pracodawcy są skłonni zapłacić za świadczoną pracę osobom samozatrudnionym równowartość kosztów pracy, jakie ponoszą w przypadku zatrudniania pracowników na umowę o pracę. W badaniu uwzględniono przede wszystkim zmiany zasad ustalania kwoty wolnej, kwot składek na ubezpieczenie społeczne, wprowadzenia zasady złotówka za złotówkę, wprowadzenia świadczenia wychowawczego „500+”.

Na potrzeby przeprowadzonych symulacji przyjęto, że:

- samozatrudnieni płacą składki na ubezpieczenia społeczne według ogólnie obowiązujących zasad,

- osoby samozatrudnione są według skali podatkowej,

- uzyskiwany przez samozatrudnionych dochód brutto-brutto mieści się w przedziale od 0 do $12500 \mathrm{zł}$.

Analizę przeprowadzono dla dwóch typów gospodarstw domowych: gospodarstwa jednoosobowego oraz gospodarstwa czteroosobowego składającego się z jednej osoby dorosłej pracującej, jednej osoby dorosłej niepracującej i dwójki dzieci. Dzięki temu możliwe było określenie, czy wprowadzone zmiany są neutralne ze 
względu na rodzaj gospodarstwa domowego. Na rysunkach 2-3 przedstawiono wpływ zmian w systemie obciążeń fiskalnych oraz transferów w latach 2015-2017 na opłacalność samozatrudnienia gospodarstwa jednoosobowego.

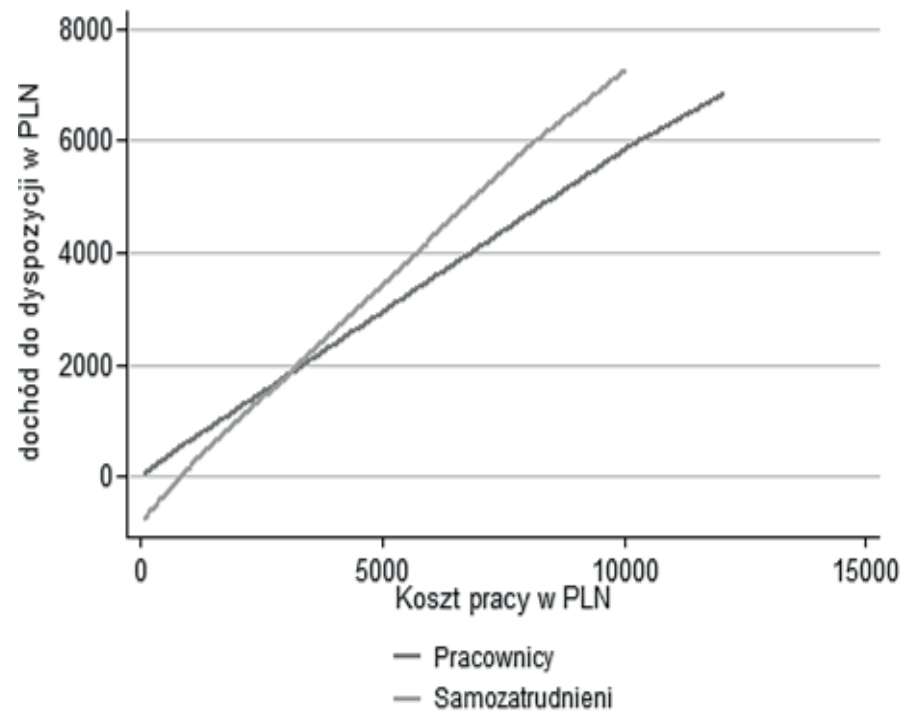

Rys. 2. Ograniczenie budżetowe dla jednoosobowego gospodarstwa domowego w roku 2015

Źródło: opracowanie własne na podstawie symulacji w modelu EUROMOD.

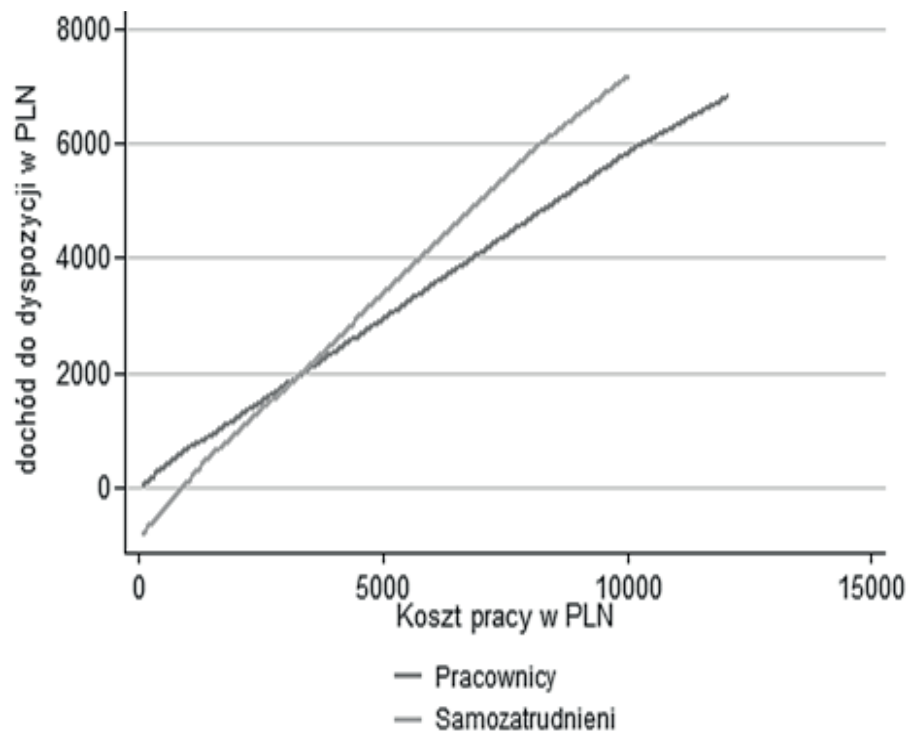

Rys. 3. Ograniczenie budżetowe dla jednoosobowego gospodarstwa domowego w roku 2017 Źródło: opracowanie własne na podstawie symulacji w modelu EUROMOD. 
Z przedstawionych wykresów wynika, że opłacalność samozatrudnienia rośnie wraz z poziomem kosztu zatrudnienia, przy czym istnieje pewna graniczna wartość, poniżej której samozatrudnienie nie opłaca się.

Wprowadzone w latach 2015-2017 zmiany w systemie obciążeń fiskalnych oraz systemie transferów socjalnych nie wpłynęły znacząco na bodźce do podejmowania samozatrudnienia w przypadku jednoosobowych gospodarstw domowych. Poziom dochodu brutto przed składkami pracodawcy, powyżej którego bardziej opłaca się samozatrudnienie, wzrósł o około 200 zł. Zmiana ta w głównej mierze związana była ze wzrostem kwoty ubezpieczeń społecznych ponoszonych przez samozatrudnionych. Inaczej jest w przypadku gospodarstw domowych, w których obok zatrudnionego znajdują się osoby pozostające na utrzymaniu.

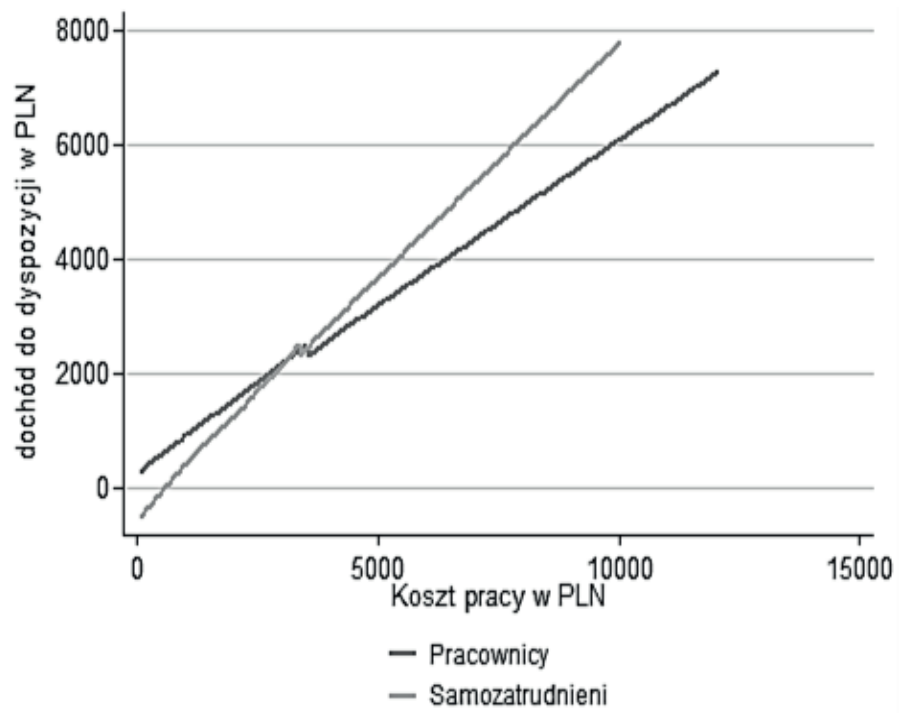

Rys. 4. Ograniczenie budżetowe dla gospodarstwa domowego $2+2$ w roku 2015

Źródło: opracowanie własne na podstawie symulacji w modelu EUROMOD.

W odniesieniu do gospodarstw domowych, które ze względu na większą liczbę członków mają możliwość uzyskania wyższej pomocy w drodze transferów socjalnych, zauważa się, że wprowadzone w latach 2015-2017 zmiany znacznie utrudniły wybór między podjęciem zatrudnienia i samozatrudnienia. W stosunkowo wąskim przedziale kosztu pracy wykres dochodu do dyspozycji osoby zatrudnionej i samozatrudnionej przecina się aż czterokrotnie. Oznacza to, że aż czterokrotnie zmienia się optymalna ze względu na poziom dochodu do dyspozycji forma zatrudnienia. Dla porównania w systemie funkcjonującym w roku 2015 takie punkty przecięcia były tylko dwa. Analizując najwyżej położony punkt przecięcia dochodu do dyspozycji osoby samozatrudnionej i osoby zatrudnionej, można stwierdzić, że poziom 


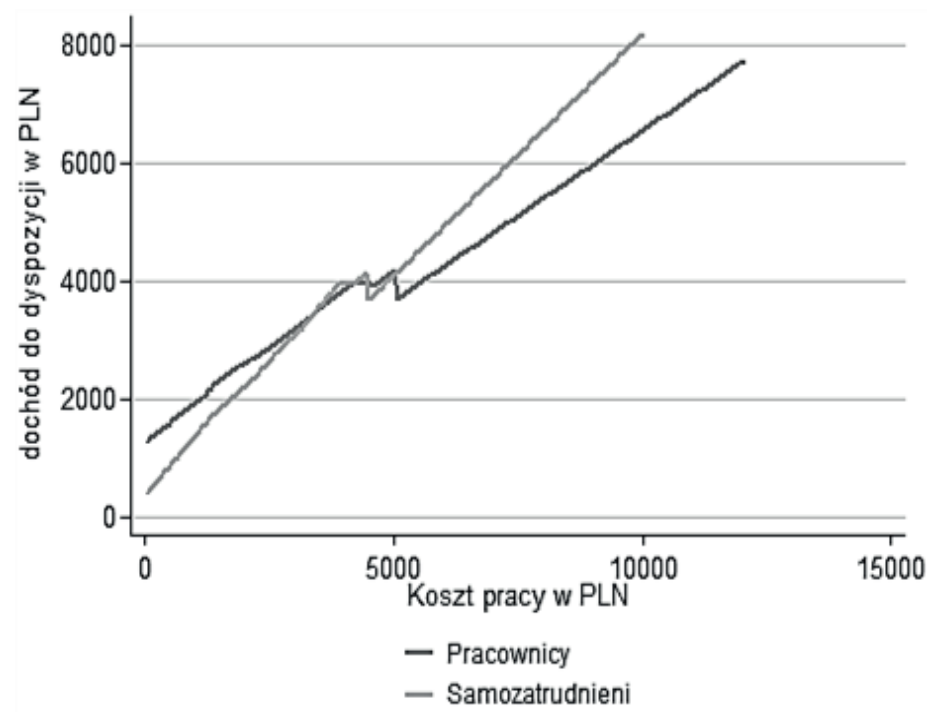

Rys. 5. Ograniczenie budżetowe dla gospodarstwa domowego 2+2 w roku 2017

Źródło: opracowanie własne na podstawie symulacji w modelu EUROMOD.

kosztu pracy, powyżej którego gospodarstwo domowe skorzysta na samozatrudnieniu, wzrósł o około $1500 \mathrm{zt}$. W głównej mierze związane jest to z wprowadzeniem programu 500+. Zastosowane w przypadku świadczenia na pierwsze dziecko kryterium dochodowe może skutkować tym, że uzyskanie przez samozatrudnienionego niewielkiej korzyści związanej z niższym poziomem obciążeń składkami na ubezpieczenia społeczne spowoduje utratę prawa do świadczenia na pierwsze dziecko.

\section{Zakończenie}

Przedstawione rozważania pozwoliły sformułować wniosek, że samozatrudnienie nie jest zjawiskiem neutralnym dla gospodarki. Dowodzi to potrzeby analizy bodźców skłaniających do podejmowania pracy na własny rachunek. Jednocześnie na podstawie studiów literatury można uprawdopodobnić hipotezę, że opodatkowanie może stanowić czynnik wpływający na decyzje gospodarstw domowych o podjęciu samozatrudnienia. Jednak, jak wykazano na podstawie symulacji, dochód netto gospodarstw domowych może istotnie różnić się od dochodu do dyspozycji - co dotyczy zwłaszcza najmniej zamożnych gospodarstw domowych. W związku z tym, badając wpływ państwa na bodźce skłaniające do samozatrudnienia, należy uwzględnić nie tylko obciążenia podatkowe i parapodatkowe, ale także transfery socjalne.

Analizując wpływ zmian, które w latach 2015-2017 wprowadzono w opodatkowaniu, składkach na ubezpieczenia społeczne oraz transferach socjalnych, wykaza- 
no, że zarówno przed zmianami, jak i po zmianach opłacalność samozatrudnienia rośnie wraz z poziomem dochodu. Ponadto dowiedziono, że wpływ wprowadzonych zmian na bodźce do samozatrudnienia był zróżnicowany w zależności od struktury gospodarstw domowych. Najmniejszy wpływ na opłacalność samozatrudnienia przeprowadzone zmiany miały w gospodarstwach jednoosobowych. Znacznie silniej wpłynęły one na bodźce do samozatrudnienia gospodarstw wieloosobowych z dziećmi. W obu przypadkach zmiany skutkowały wzrostem dochodu, przy którym opłacalna jest zmiana zatrudnienia na samozatrudnienie, co oznacza osłabienie bodźców do podejmowania pracy na własny rachunek.

Należy podkreślić, że przeprowadzone symulacje skłaniają do konkluzji, iż wprowadzone w latach 2015-2017 zmiany w obciążeniach fiskalnych oraz transferach socjalnych znacznie utrudniły wybór między zatrudnieniem a samozatrudnieniem. Wynika to $\mathrm{z}$ faktu, że w dość wąskim przedziale dochodu system obciążeń fiskalnych i transferów socjalnych tworzy niestabilne i sprzeczne bodźce do samozatrudnienia. Ponadto trudno znaleźć uzasadnienie dla zmian, które w znacznie większym stopniu wpłynęły na skłonność do samozatrudnienia gospodarstw wieloosobowych z dziećmi, niż miało to miejsce w przypadku gospodarstw jednoosobowych. Dowodzi to zatem, iż implementując analizowane zmiany, skupiono się jedynie na osiągnięciu bezpośrednich celów redystrybucyjnych, nie uwzględniono jednak ich daleko idących konsekwencji dla zachowań ekonomicznych gospodarstw domowych.

\section{Literatura}

Blau D.M., 1987, A time-series analysis of self-employment in the United States, Journal of Political Economy, 95 (3), s. 445-467.

Block J., Sandner P., 2009, Necessity and opportunity entrepreneurs and their duration in self-employment: Evidence from German micro data, Journal of Industry, Competition and Trade, vol. 9, no. 2, s. 117-337.

Bruce D., 2000, Effects of the United States tax system on transitions into self-employment, Labour Economics no. 7, s. 545-574.

Crawford C., Freedman J., 2010, Small Business Taxation, [w:] Dimensions of Tax Design, Oxford University Press, New York.

Dawson Ch., Henley A., Why Do Individuals Choose Self-Employment?, Paul Latreille, IZA.

Decker R., Haltiwanger J., Jarmin R., Miranda J., 2014, The role of entrepreneurship in US job creation and economic dynamism, Journal of Economic Perspectives, vol. 28, no. 3, s. 3-24.

Dvouletý O., Lukeš M. 2016, Review of empirical studies on self-employment out of unemployment: Do self-employment policies make a positive impact?, International Review of Entrepreneurship, 2 Article \#1540, 14(3), s. 361-376.

Feldstein M., 1999, Tax avoidance and the deadweight loss of the income tax, Review of Economics and Statistics, 81, s. 674-80.

Figari F., Paulus A., Sutherland,H., Microsimulation and policy analysis, the Handbook of Income Distribution, vol. 2.

Gordon R.H., Slemrod J.B., 2000, Are "Real” Responses to taxes Simply Income Shifting between Corporate and Personal Tax Bases?, Does Atlas Shrug, [w:] The Economic Consequences of Taxing the Rich. 
Haltiwanger J., Jarmin R.S., Miranda J., 2013, Who creates jobs? Small vs. large vs. young, Review of Economics and Statistics, no. 95(2), s. 347-61.

Harju J., Matikka T., 2013, The elasticity of taxable income and income-shifting between tax bases: What is "real" and what is not?, Working Papers no. 1313, Oxford University Centre for Business Taxation.

Institute for Fiscal Studies, Mirrlees J. (red), 2011, Tax By Design: The Mirrlees Review, OUP Catalogue, Oxford University Press, no. 9780199553747.

Lofstrom M., 2009, Does self-employment increase the economic well-being of low-skilled workers?, IZA Discussion Paper, no. 4539.

Long J.E., 1982, The income tax and self-employment, National Tax Journal, no. 35, s. 31-42.

Moore R.L., 1983, Self-employment and the incidence of the payroll tax, National Tax Journal, no 36, s. 491-501.

Orcutt G.H., 1957, A new type of socio-economic system, The Review of Economics and Statistics, vol. 39 , no. 2 .

Parker S., 1996, A time series model of self-employment under uncertainty, Economica, no. 63, s. 459-475 .

Scheutze H.J., 1998, Taxes, economic conditions, and recent trends in male selfemployment: A Canada- U.S. comparison, Working Paper.

Shane S., 2009, Why encouraging more people to become entrepreneurs is bad public policy, Small Business Economics, 33(2), s. 141-149.

Sutherland H., Figari F., 2013, EUROMOD: The European Union tax-benefit microsimulation model, International Journal Of Microsimulation, no. 6(1), s. 4-26. 